\title{
Genotypic and Phenotypic Characterization, Antibiotic Resistance and Virulence Patterns of Staphylococcus aureus Isolated form Goat Mastitis
}

Yasser M. Kamel

Infectious Diseases Unit, Department of Animal Health, Division of Animal and Poultry Production, Desert Research Center, Matariya, Cairo, P.O. Box: 11562, Egypt

\section{ARTICLE HISTORY}

\section{Received: 16.08 .2020}

Revised: 25.10 .2020

Accepted: 30.10 .2020

Address correspondences to Rasha M. Elkenany, PhD; Tel: +2 01222203735, E-mail: ymahmod@kau.edu.sa

\section{ABSTRACT}

\begin{abstract}
Objective: To determine the phenotypic and genotypic characterization of the virulence and antimicrobial susceptibility of $S$. aureus.

Design: Descriptive study

Samples: 175 raw goat milk samples

Procedures: A total of $87 \mathrm{~S}$. aureus strains was isolated from goat with mastitis in north-west cost of Egypt. PCR technique was used to detect genes coding some virulence and antimicrobial properties while phenotypic antimicrobial susceptibility was determined by the disc diffusion method. Results: Most S. aureus isolates were resistant to amoxycillin (89.7\%), penicillin G $(88.5 \%)$, and ampicillin $(86 \%)$ while were less resistant to other members of $\beta$-lactam group as cefoxitin $(17.2 \%)$ and ceftriaxone $(10.3 \%)$.The lowest resistant rates were toward fluroquinolone group members; ciprofloxacin, levofloxacin and ofloxacin in rates $1.2 \%, 2.3 \%$ and $4.5 \%$, respectively. Tetracycline showed the highest level of phenotypic resistance (34.6\%) and prevalence of $a$ tetK gene (39.1\%). The virulence factors, spa and coa exhibited prevalence rate of $6.9 \%$ and $8 \%$, respectively with significant relationship between them.

Conclusion and Clinical relevance: The problem of antimicrobial resistance needs strict measures to limit the indiscriminate use of antibiotics and concerted research efforts to limit the spread of resistant bacteria, which will negatively affect human health and control of the infectious diseases in both humans and animals.
\end{abstract}

Keywords: S. aureus, virulence, antimicrobial resistance, mastitis, goat

\section{INTRODUCTION}

Staphylococcus aureus (S. aureus) is one of the most clinically important opportunistic contagious pathogens of humans and animals. S. aureus has particular attention as being one of the most common foodborne pathogen that cause a wide range of clinical infections, including clinical and subclinical mastitis in small ruminants [1]. However, identifying infected goat may be difficult, as unlike cattle, the high number of somatic cells and positive result in the California mastitis test is not certainly dependable indicator of mastitis among small ruminants [2].

It is known that the use of antimicrobial drugs in humans and animals in developing countries is not sufficiently controlled by the competent authorities. As a result, many resistant strains of $S$. aureus can be frequently isolated [3]. Therefore, it is necessary to identify these strains and understand the resistance mechanism in parallel with raising awareness of the importance of this issue in those countries to be wiser in using antibacterial agents to counteract the resistant bacteria in both humans and animals. While the phenotypic and genotypic characteristics of $S$. aureus isolated from bovine milk are well identified, similar data on those isolated from small ruminants are rare [4-6]. Data on $S$. aureus detected in small ruminants related to genetic characterization, virulence factors and antimicrobial resistance are important to identify different potential mode of transmission, develop and improve management strategies for infected goats' herds, and discover effective therapeutic medications. Consequently, the aim of this study was to identify the virulence characterization and antimicrobial resistance of $S$. aureus isolated from goat's milk at the phenotypic and genotypic levels.

\section{MATERIALS AND METHODS}

\subsection{Sample collection}

From small Bedouin goat herds that are living in the north-west coast of Egypt, a total of 175 raw goat milk samples with clinical signs of mastitis; udders inflammation accompanied with or without changing in consistency and/or color of milk were randomly collected. The teats were disinfected with alcohol and the first milk stream was discarded before collecting the milk samples.

\subsection{Sample processing and bacterial isolation}

The collected raw milk samples were subjected to inoculation onto $5 \%$ sheep blood agar plates that were incubated aerobically at $37^{\circ} \mathrm{C}$ for $24 \mathrm{~h}$. Milk samples were considered infected when three or more dissimilar colony types were founded [7]. 
S. aureus strains were isolated from collected raw milk samples according to the EN ISO 6888-1 standard procedure of the International Organization for Standardization [8] as follows: briefly, milk samples were spread onto Baird-Parker agar plates supplemented with $5 \%$ tellurite egg yolk emulsion and incubated aerobically at $37^{\circ} \mathrm{C}$ for $48 \mathrm{~h}$. The putative colonies were chosen and confirmed by the coagulase test using rabbit plasma and positive colonies were subjected to Gram-staining and biochemical tests (catalase reaction, DNase, beta hemolysis, clumping factor and anaerobic mannitol fermentation). Positive colonies, as a result of these tests, were considered phenotypically as $S$. aureus. All presumptive strains were grown overnight in Luria broth supplemented with glycerol ( $20 \% \mathrm{vol} / \mathrm{vol})$, which were then stored at $-80^{\circ} \mathrm{C}$ for further investigations.

\subsection{Molecular Identification and characterization of S. aureus}

Total DNAs from all apparent $S$. aureus isolates were subjected to the conventional boiling method for extraction of total DNA as depicted previously [1] and the extracted DNA was quantified by using Nanodrop spectrophotometer and stored at $-20{ }^{\circ} \mathrm{C}$ to be used for molecular detection of virulence and antimicrobial resistant genes. All samples DNA and those of S. aureus ATCC 29213 (positive control), and S. epidermidis ATCC 12228 (negative control) were subjected to PCR procedure to emphasize $S$. aureusisolates via amplifying the nuc gene as described previously [10]. Briefly, a total volume of $20 \mu \mathrm{l}$, containing $2 \mu \mathrm{l}$ of sample DNA, $2 \mu \mathrm{l}$ of 10X PCR buffer, $4 \mu$ l of dNTPs in concentration $1 \mathrm{mM}, 1 \mu \mathrm{l}$ of $\mathrm{MgCl}_{2}$ in concentration $50 \mathrm{mM}, 1 \mu \mathrm{l}$ of each nuc forward and reverse primers in concentration $10 \mathrm{Pmol}$ (primer sequences are shown in table 1), $0.25 \mu \mathrm{l}$ of Taq DNA polymerase in concentration of $5 \mu / \mu \mathrm{l}$ and finally $8.75 \mu \mathrm{l}$ of $\mathrm{dH} 2 \mathrm{O}$. Amplification was carried out using a thermocycler according to the following PCR steps of an initial denaturation for $5 \mathrm{~min}$ at $94^{\circ} \mathrm{C}$; followed by 30 cycles of $94^{\circ} \mathrm{C}$ for $1 \mathrm{~min}, 50^{\circ} \mathrm{C}$ for 1 min, and $72^{\circ} \mathrm{C}$ for $2 \mathrm{~min}$, and a final extension step at $72^{\circ} \mathrm{C}$ for 10 min. Lastly, ethidium bromide stained PCR products were detected on $2 \%$ agarose gel by using electrophoresis. The appearance of the amplified DNA fragments at $270 \mathrm{bp}$ was considered positive result. Molecular grade water and $S$. aureus ATCC29213 were used as negative and positive controls, respectively (Table 1 ).

\subsection{Antimicrobial susceptibility testing}

Confirmed S. aureus isolates were subjected to KirbyBauer disk diffusion method for detection the antibiotic sensitivity [17].The antibiotics used and their concentration are shown in table 2 . Briefly, the sample was inoculated into nutrient broth and incubated for $24 \mathrm{~h}$ at $37^{\circ} \mathrm{C}$. A loop of 100 ul of growth was streaked onto Mueller-Hinton agar plates. The antibiotic discs were applied onto the dried inoculated agar plates and incubated at $37^{\circ} \mathrm{C}$ for $24 \mathrm{~h}$. The zones of inhibition were measured, and results were recorded as sensitive (S), intermediate (I) or resistant (R) in accordance with the CLSI guidelines [17].

\subsection{Molecular Detection of Virulence, Antimicrobial Resistance Genes}

The isolated strains were subjected to multiplex PCR for investigation of virulence and antimicrobial resistance genes according to a previously described method [18]. Briefly, each PCR assay was carried out in a $15 \mu \mathrm{L}$ comprising 4 ul extracted DNA, $0.5 \mu$ l of each forward and reverse primer; the details of each primer are summarized in table1, and $3 \mu$ of double distilled water. Reactions were proceeded according to the following parameters: initial denaturation at $95^{\circ} \mathrm{C}$ for $3 \mathrm{~min}$ followed by 36 cycles including denaturation for $30 \mathrm{~s}$ at $95^{\circ} \mathrm{C}$, annealing for $45 \mathrm{~s}$ at different temperatures (table 1) according the primer used, extension for $1 \mathrm{~min}$ at $72^{\circ} \mathrm{C}$ and last extension for $5 \mathrm{~min}$ at $72^{\circ} \mathrm{C}$. The amplified bands were detected on a $2 \%$ ethidium bromide stained agarose gel using $1 \mathrm{X}$ tris acetate EDTA (TAE) as a buffer. A positive control and negative control were set up with every amplification assay.

\subsection{Statistical Analysis}

The data were subjected to statistical analysis SPSS (ver. 25), version 25 statistical package. Chi-square test was used to estimate the relationships between the variables, $p<0.05$ was considered as statistically significant. Evaluation of the strength and direction of the relationship between the antibiotic resistance and virulence genes was detected using two tailed Pearson's correlation test.

\section{RESULTS}

\subsection{Prevalence of S. aureus in collected samples}

In the current study, a total of 175 collected milk samples from goats were suffering from mastitis, 135 samples were harboring microbial infection. Out of 135 infected milk samples, 87 (64.4\%) were confirmed to be $S$. aureus by detection of nuc gene PCR methods. Furthermore, four $S$. aureuss trains $(10.3 \%, 9 / 87)$ were classified as MRSA isolate based on their embracing the mecA gene. For determination of association between bacteriological and molecular methods for the detection of $S$. aureus, the results were subjected to the2-tailed Pearson's correlation test. Results revealed a high significant $(p<0.001)$, positive correlation (69.6\%).

\subsection{Antimicrobial Resistance Assay}

In the present study, all isolated strains of $S$. aureus were tested against various types of antimicrobial agents that are or were using in treatment of $S$. aureus infected cases to determine the phenotypic resistance profile for each isolate, as shown in table 2. Figure 1.

Most of S.aureus isolates were verified as multi-drug resistant S. aureus (MDR-SA), where72 (82.8\%) isolates were resistant to three or more antibiotics, as shown in figure 1 . It was found that fluroquinolone members: ciprofloxacin, levofloxacin, and ofloxacin showed the lowest resistance ratio of $1.2 \%, 2.3 \%$, and $4.5 \%$, respectively, while amoxycillin, penicillin, and ampicillin displayed the highest resistant in ratios of $89.7 \%, 88.5 \%$, and $86.2 \%$, respectively. Thirty-five isolates $(40.3 \%)$ were classified as MRSA by cefoxitin disk diffusion tests. All S. aureus isolates were susceptible to linezolid and vancomycin. 
Table 1. Sequences of primer sets used to amplify specific virulence and antibiotic resistance genes.

\begin{tabular}{|c|c|c|c|}
\hline Gene & Primer sequence $\left(5^{\prime}-3^{\prime}\right)$ & $\begin{array}{c}\text { Amplicon } \\
\text { size (bp) }\end{array}$ & Reference \\
\hline nuc & $\begin{array}{l}\text { F-GCGATTGATGGTGATACGGTT } \\
\text { R-AGCCAAGCCTTGACGAACTAAAGC }\end{array}$ & 270 & 11 \\
\hline mecA & $\begin{array}{l}\text { F- TCCAGATTACAACTTCACCAGG } \\
\text { R-CCACTTCATATCTTGTAACG }\end{array}$ & 162 & 12 \\
\hline tetK & $\begin{array}{l}\text { F-TCGATAGGAACAGCAGTA } \\
\text { R-CAGCAGATCCTACTCCTT }\end{array}$ & 169 & 13 \\
\hline $\begin{array}{l}\operatorname{aac}(60)- \\
\operatorname{aph}\left(2^{\prime \prime}\right)\end{array}$ & $\begin{array}{l}\text { F-TAATCCAAGAGCAATAAGGGC } \\
\text { R-GCCACACTATCATAACCACTA }\end{array}$ & 227 & 13 \\
\hline coa & $\begin{array}{l}\text { F-CGAGACCAAGATTCAACAAG } \\
\text { R-AAAGAAAACCACTCACATCA }\end{array}$ & 730 & 13 \\
\hline spa & $\begin{array}{l}\text { F-CAAGCACCAAAAGAGGAA } \\
\text { R-CACCAGGTTTAACGACAT }\end{array}$ & 180 & 14 \\
\hline see & $\begin{array}{l}\text { F-TAGATAAAGTTAAAAAACAAGC } \\
\text { R-TAACTTACCGTGGACCCTTC }\end{array}$ & 170 & 15 \\
\hline sea & $\begin{array}{l}\text { F- CCTTTGGAAACGGTTAAAACG } \\
\text { R-TCTGAACCTTCCCATCAAAAAC }\end{array}$ & 127 & 16 \\
\hline
\end{tabular}

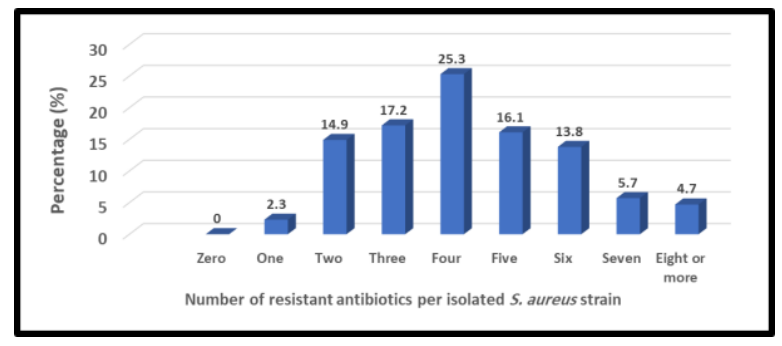

Figure 1. Resistance of $S$. aureus strains to one or more antibiotics.

Table3: Presence of virulence and antimicrobial resistant genes in isolated $S$. aureus strains.

\begin{tabular}{|c|c|c|c|c|c|c|c|}
\hline \multirow{3}{*}{$\begin{array}{l}\text { No. of } \\
\text { strains } \\
\text { containing } \\
\text { genes }\end{array}$} & \multicolumn{3}{|c|}{$\begin{array}{c}\text { Antibiotic resistance } \\
\text { genes }\end{array}$} & \multicolumn{4}{|c|}{ Virulence related genes } \\
\hline & $a a c$ & tetK & mecA & coa & sea & see & $s p a$ \\
\hline & 9 & 34 & 23 & 7 & 21 & 4 & 6 \\
\hline Percent (\%) & 10.3 & 39.1 & 26.4 & 8 & 24.1 & 4.6 & 6.9 \\
\hline
\end{tabular}

Table 4. Determination of the relationship between the different genetic contents by using Pearson`s correlation and P-values.

\begin{tabular}{|c|c|c|c|c|c|c|c|}
\hline & $a a c$ & tetk & mecA & $\mathrm{coa}$ & sea & see & $s p a$ \\
\hline$a a c$ & 1 & $\begin{array}{l}-0.059 \\
(0.243)\end{array}$ & $\begin{array}{l}0.091 \\
(0.239)\end{array}$ & $\begin{array}{l}-0.031 \\
(0.601)\end{array}$ & $\begin{array}{l}-0.087 \\
(0.165)\end{array}$ & $\begin{array}{l}-0.089 \\
0.197\end{array}$ & $\begin{array}{l}0.045 \\
(0.561)\end{array}$ \\
\hline tetk & $\begin{array}{l}-0.059 \\
(0.243)\end{array}$ & 1 & $\begin{array}{l}-0.059 \\
(0.243)\end{array}$ & $\begin{array}{l}-0.071 \\
(0.297)\end{array}$ & $\begin{array}{l}-0.034 \\
(0.584)\end{array}$ & $\begin{array}{l}0.025 \\
(0.674)\end{array}$ & $\begin{array}{l}0.032 \\
(0.654)\end{array}$ \\
\hline $\operatorname{mec} A$ & $\begin{array}{l}0.091 \\
(0.239)\end{array}$ & $\begin{array}{l}-0.059 \\
(0.243)\end{array}$ & 1 & $\begin{array}{l}0.150^{*} \\
(0.250)\end{array}$ & $\begin{array}{l}0.015 \\
(0.889)\end{array}$ & $\begin{array}{l}0.077 \\
(0.335)\end{array}$ & $\begin{array}{l}0.025 \\
(0.760)\end{array}$ \\
\hline coa & $\begin{array}{l}-0.031 \\
(0.601)\end{array}$ & $\begin{array}{l}-0.071 \\
(0.297)\end{array}$ & $\begin{array}{l}0.150^{*} \\
(0.250)\end{array}$ & 1 & $\begin{array}{l}-0.035 \\
(0.688)\end{array}$ & $\begin{array}{l}-0.029 \\
(0.713)\end{array}$ & $\begin{array}{l}0.310^{*} \\
* \\
(0.000)\end{array}$ \\
\hline sea & $\begin{array}{l}-0.087 \\
(0.165)\end{array}$ & $\begin{array}{l}-0.034 \\
(0.584)\end{array}$ & $\begin{array}{l}0.015 \\
(0.889)\end{array}$ & $\begin{array}{l}-0.035 \\
(0.688)\end{array}$ & 1 & $\begin{array}{l}0.320^{* *} \\
(0.000)\end{array}$ & $\begin{array}{l}-0.014 \\
(0.792)\end{array}$ \\
\hline see & $\begin{array}{l}-0.089 \\
0.197\end{array}$ & $\begin{array}{l}0.025 \\
(0.674)\end{array}$ & $\begin{array}{l}0.077 \\
(0.335)\end{array}$ & $\begin{array}{l}-0.029 \\
(0.713)\end{array}$ & $\begin{array}{l}0.320 * \\
* \\
(0.000)\end{array}$ & 1 & $\begin{array}{l}-0.088 \\
(0.229)\end{array}$ \\
\hline$s p a$ & $\begin{array}{l}0.045 \\
(0.561)\end{array}$ & $\begin{array}{l}0.032 \\
(0.654)\end{array}$ & $\begin{array}{l}0.025 \\
(0.760)\end{array}$ & $\begin{array}{l}0.310 * * \\
(0.000)\end{array}$ & $\begin{array}{l}-0.014 \\
(0.792)\end{array}$ & $\begin{array}{l}-0.088 \\
(0.229)\end{array}$ & 1 \\
\hline
\end{tabular}

\subsection{Molecular Detection of Virulence, Antimicrobial Resistance Genes}

The isolated S. aureus strains were examined for a total of nine genes associated with virulence and antimicrobial resistance. Concerning antimicrobial genes, the most established gene was tetK $(39.1 \%)$ referring resistance to tetracycline and followed by the mecAgene (26.4\%), categorizing these isolates as methicillin resistance $S$. aureus (MRSA). On the other hand, the most prominent genes for virulence was sea $(24.1 \%)$, as shown in table3. Statistical analysis showed up the relationship between the genetic determinants (Table 4).

\section{DISCUSSION}

S. aureus has been considered an important pathogen that can cause a diverse range of infections particularly zoonotic diseases and the potential transmission of antimicrobial resistant strains especially those expressing a MDR phenotype and possessing many virulence factors including production of enterotoxins (see and sea)between farm animals and humans through close contact, handling and/or consumption of $S$. aureus contaminated food causing major warnings in both food security and healthcare sectors [19]. Since our isolates were derived from different goat husbandry places, contagious transmission is likely to occur not only within the same herd, but also between different herds, possibly mainly through grazing where they are often grazing in the same areas.

The public health importance of $S$. aureus is evident in outbreaks of poisoning via contaminated dairy products such as those that occurred in Japan and recorded as one of the largest outbreaks of foodborne illness that involved 13,420 infected individuals [20]. Additionally, many cases of dairyby-products poisoning have also been reported frequently in China [21]. Economically, mastitis often leads to a decrease in milk production and exorbitant treatment costs and may sometimes cause animal executions [20].The present study identified some virulence characterization and antimicrobial resistance of $S$. aureus isolated from raw goat's milk that would be helpful to know the antimicrobial resistance and virulence markers which can help in preventing and control the $S$. aureus contamination and protect the end customer. The high significant $(p<0.001)$ and positive correlation (69.6\%) between the conventional microbiological and molecular methods in detection of $S$. aureus indicate the importance of using both methods in parallel for identification and diagnosis of $S$. aureus infection. Although molecular detection methods are less laborious, save time, more sensitive and reliable, it may be cost-effective to start identification using conventional methods and confirm -if it is necessary- by molecular methods. The emerge of one 'superbug' with multiple antimicrobial resistance will increase the challenges facing the food security and healthcare sectors as infections become very difficult-totreat or even emerging untreatable staphylococcal 
infections.For confirmation, the World Health Organization (WHO) has reported that there is a list of infectious diseases that are now difficult to treat, and this is alarming because some antibiotics have become less effective in such a way that this infection is not responding to treatment in some

Table 2. Antimicrobial resistance of isolated S. aureus strains. cases [22].The unwise use of antimicrobial drugs has a great burden on the health care system where international antibiotic consumption exhibited $65 \%$ increase from 2000 to 2015 in developing countries [23].

\begin{tabular}{|c|c|c|c|c|c|}
\hline \multirow[t]{2}{*}{ Antimicrobial group } & \multirow[t]{2}{*}{ Antimicrobial } & \multirow[t]{2}{*}{ Conc. } & \multicolumn{3}{|c|}{ No. (\%) of isolates with Phenotypic resistance pattern } \\
\hline & & & $\mathbf{S}$ & I & $\mathbf{R}$ \\
\hline \multirow[t]{2}{*}{ Aminoglycosides } & Gentamycin & 10 ug & $57(65.5)$ & (0) & $30(34.5)$ \\
\hline & Streptomycin & 10 ug & $43(49.4)$ & $16(18.4)$ & $28(32.2)$ \\
\hline \multirow[t]{5}{*}{ B-lactams } & Amoxycillin & 25 ug & $9(10.3)$ & (0) & $78(89.7)$ \\
\hline & Ampicillin & 10 ug & $12(13.8)$ & (0) & $75(86.2)$ \\
\hline & Cefoxitin & 30 ug & $52(59.7)$ & (0) & $35(40.3)$ \\
\hline & Ceftriaxone & 30 ug & $75(86.3)$ & $3(3.4)$ & $9(10.3)$ \\
\hline & Penicillin G & $10 \mathrm{IU}$ & $10(11.5)$ & $0(0)$ & 77 (88.5) \\
\hline Phenicols & Chloramphenicol & 30 ug & $70(80.5)$ & $3(3.4)$ & $14(16.1)$ \\
\hline Macrolides & Erythromycin & 15 ug & $68(78.2)$ & $7(8)$ & $12(13.8)$ \\
\hline \multirow[t]{3}{*}{ Fluoroquinolones } & Ciprofloxacin & 5 ug & $83(95.4)$ & $3(3.4)$ & $1(1.2)$ \\
\hline & Levofloxacin & 5 ug & $84(96.6)$ & $1(1.1)$ & $2(2.3)$ \\
\hline & Ofloxacin & 5 ug & $75(86.3)$ & $8(9.2)$ & $4(4.5)$ \\
\hline Tetracyclines & Tetracycline & 30 ug & $52(59.7)$ & $5(5.7)$ & $30(34.6)$ \\
\hline $\begin{array}{l}\text { Sulfonamides and } \\
\text { synergistic agents }\end{array}$ & Cotrimoxazole & 25 ug & $57(65.5)$ & $20(23)$ & $10(11.5)$ \\
\hline
\end{tabular}

Increased recurrent exposure to antimicrobial drugs has created a selective pressure for the emergence of resistant bacteria. This is apparent from our results since most $S$. aureus isolates were resistant to amoxycillin (89.7\%), penicillin $\mathrm{G}(88.5 \%)$, and ampicillin $(86 \%)$ where they are being used injudiciously while were less resistant to other members of $\beta$-lactam group as cefoxitin (17.2\%) and ceftriaxone (10.3\%).The lowest resistant rates were toward the less common antibiotic used in farm animals' treatment as fluroquinolone group members; ciprofloxacin, levofloxacin and ofloxacin in rates $1.2 \%, 2.3 \%$ and $4.5 \%$, respectively. Our study revealed similar resistance with previous recorded work [24] towards aminoglycosides; gentamycin (34.5\%) and streptomycin (32.2\%) and tetracycline (34.6\%).

Regarding macrolides, lower resistance was reported with erythromycin $(13.8 \%)$ as compared with the resistance rate (23\%) in recent previous study [25]. Detection of livestock associated $S$. aureus (LA-SA) including MRSA and MDR strains among goats have been reported in many international studies [26-28]. In the current study, mecA gene had been recognized in $26.4 \%$ of the $S$. aureus isolates that were classified as MRSA.

Molecular identification and characterization are essential for the classification and understanding of various microorganisms. As MRSA strains have been isolated from many sources; patients, livestock and wastewater, plenty of studies have been hypothesized to demonstrate and explain genetics of $S$. aureus that includes genes responsible for antibiotic resistance along with virulence genes [29]. The gene mecA was the benchmark gene in detection of methicillin resistance, however, many recent studies displayed the failure of mecA in detection of MRSA strains [30].A novel divergent mecA homologue methicillin resistance mechanism gene named $\operatorname{mec} C$ was recently discovered in S. aureus [31]. This gene has been recovered from humans, ruminants and other animals [32], but to the extent of our knowledge" had not recovered yet in Egypt [33]. In the same context, mecC was not detected in the tested isolates of our study that phenotypically resist cefoxitin and so, mecA gene was considered our target gene for detection of MRSA strains. Moreover, the phenotypic resistance for cefoxitin (40.3\%) was significantly higher than those detected depending on genetical basis (26.4\%). The high obtained phenotypic MRSA may attribute to one or more genetic mechanisms that were not explored in this study. However, the previous studies established many mechanisms of methicillin resistance such as the penicillin-binding protein $2 a$ (PBP2a) regulated by theblaZ-blal-blaR1 and mecA-mecl$m e c R /$ systems [34] and also, the expression of the mecA gene is highly variable and dependent on different factors. In addition, the femA gene encodes proteins affect the expression level of methicillin resistance of $S$. aureus [35]. This may explain the difference in phenotypic and genetic outcomes in our study.

Tetracycline resistance are wide-ranging in bacterial species via conjugation or transposons particularly among those of MDR [36]. Prolonged use paving the way to emergence of tetracycline resistant species which is a serious concern for both human and animal health due to the possibility of transferring the resistant genes to humans from goats and vice versa [37]. In many countries including Egypt, tetracycline is the most used antibiotics for mastitis treatment and routinely added to water as a prophylactic protocol [38], so it is not surprising to get a high level of phenotypic resistance (34.6\%) and thus the highest prevalence of a tetK gene $(39.1 \%)$ among all investigated genes. Our results of tetracycline resistance are parallel to some and in contrast with others of previous studies [39-40]. Differences in outcomes can be attributed to differences in resistance gene profiles of isolates where three resistance 
mechanisms of tetracycline have been well described: efflux, ribosomal protection, and enzymatic inactivation of tetracycline drugs and there are multiple strain-specific factors in clinical isolates affecting uptake the resistance genes. Moreover, the level of tetracycline-specific pumps expression plays a synchronized role in the overall tetracyclines susceptibility [41]. Based on this result, we can say that we are in critical situation and urgent need to take strict measures to reduce the use of tetracycline.

The prevalence of many virulence-associated genes in $S$. aureus has been investigated worldwide. The current study showed law prevalence but significant relation $(\mathrm{p}<0.05)$ between endotoxin genes, sea $(24.1 \%)$ and see $(4.6 \%)$, as shown in table 3.The low frequency of these genes indicates that these isolates are less likely to cause toxin disease [42]. This is consistent with the type of the most samples where were taken from asymptomatic animals. The virulence factors, spa and coa exhibited prevalence rate of $6.9 \%$ and $8 \%$, respectively. These proportions are congruent with previous studies that reported spa rate of $9.17 \%$ and $9 \%$ while was $11 \%$ and $5 \%$ for coa [43-44]. Interestingly, the virulence gene coa control the coagulase activity, and the low frequency of this gene indicates that most of the $S$. aureus isolates are coagulase-negative strains (CNS). This result offers an evident that CNS serve as a reservoir of antimicrobial resistance genes that can be exchanged to other bacteria and add more challenges to the control and treatment of mastitis and that could potentially risk on human health [45]. Furthermore, there are co-existence of virulence factors confirmed by the Pearson's correlation that states positive and significant relationships between coa and spa $(p=0.000)$ as shown in table4.

Concisely, since our isolates were derived from different goat husbandry places, contagious transmission is likely to occur not only within the same herd, but also between different herds, possibly mainly through grazing where they are often grazing in the same areas. The intricacy of antimicrobial resistance needs synergy of research efforts to determine the interaction between bacterial pathogens in animal-human interfaces, which will help us in controlling the antimicrobial resistance. The findings of our study showed lower rates of the investigated genotypic as compared to the phenotypic characteristics. This can be assigned to that certain phenotypic property needs many genes for its expression. Furthermore, the low frequencies seen for the virulence genes do not certainly mean that the strains have no or limited virulence effect. In this study, mecC gene for methicillin resistance couldn't be detected but this may be draw attention for further prevalence studies on large scale and frequent surveillance. Since our isolates were derived from different goat husbandry places, contagious transmission is likely to occur not only within the same herd, but also between different herds, possibly mainly through grazing where they are often grazing in the same areas therefore, The application of strict control systems in animal production systems is increasingly necessary to prevent or reduce the spread of livestock associated $S$. aureus and prevent possible outbreaks as well. The intricacy of antimicrobial resistance needs synergy of research efforts to determine the interaction between bacterial pathogens in animal-human interfaces, which will help us in controlling the antimicrobial resistance.

\section{REFERENCES}

[1] Wu, S.; Huang, J.; Wu, Q.; Zhang, J.; Zhang, F.; Yang, X.; Wu, H.; Zeng, H.; Chen, M.; Ding, Y.; et al. Staphylococcus aureus Isolated from Retail Meat and Meat Products in China: Incidence, Antibiotic Resistance and Genetic Diversity. Front. Microbiol. 2018, 9, 2767. https://doi.org/10.3389/fmicb.2018.02767

[2] Merz A., Stephen R., Johler S. Staphylococcus aureus Isolates from Goat and Sheep Milk Seem to Be Closely Related and Differ from Isolates Detected from Bovine Milk. Front. Microbiol. 2016, 7:319. https://doi.org/10.3389/fmicb.2016.00319

[3] Dilnessa T, Bitew A. Prevalence and antimicrobial susceptibility pattern of methicillin resistant Staphylococcus aureus isolated from clinical samples at Yekatit 12 hospital medical college, Addis Ababa. Ethiopia BMC InfectDiseases. 2016, 16:398. https://doi.org/10.1186/s12879016-1742-5

[4] Linage B, Rodríguez-Calleja JM, Otero A, García-López ML, Santos J. Characterization of coagulase-positive staphylococci isolated from tank and silo ewe milk. J Dairy Sci.2012, 95: 1639-1644. https://doi.org/10.3168/jds.2011-4734

[5] Eriksson J., Espinosa-Gongora C., Stamphoj I., Larsen A. R., and Guardabassi L., "Carriage frequency, diversity and methicillin resistance of Staphylococcus aureus in Danish small ruminants. Vet Microbiol 2013, 163: 10-115. https://doi.org/10.1016/j.vetmic.2012.12.006

[6] Smith, E.M., Needs, P.F., Manley, G. and Green, L.E. Global distribution and diversity of ovine-associated Staphylococcus aureus. Infect Genet 2014, 22, 208-215. https://doi.org/10.1016/j.meegid.2013.09.008

[7] Hiitiö H., Riva R., Autio T., Pohjanvirta T., Holopainen J., Pyörälä S. \& Pelkonen S. Performance of a real-time PCR assay in routine bovine mastitis diagnostics compared with in-depth conventional culture. J Dairy Res. 2015, 82:200-208. https://doi.org/10.1017/S0022029915000084

[8] International Standard Office: Microbiology of food and animal feeding stuffs - horizontal method for the enumeration of coagulase-positive staphylococci, EN ISO 6888-1 (Staphylococcus aureus and other species), 2003.

[9] Ribeiro, J.C.; Tamanini, R.; Soares, B.F.; De Oliveira, A.M.; De Godoi Silva, F.; Da Silva, F.F.; Augusto, N.A.; Beloti, V. Efficiency of boiling and four other methods for genomic DNA extraction of deteriorating sporeforming bacteria from milk. Semin. Agrar. 2016, 37, 3069-3078. https://doi.org/10.5433/1679-0359.2016v37n5p3069

[10] Murakami, K., Minamide, W., Wada, K., Nakamura, E., Teraoka, H., and Watanabe, S. Identification of methicillin-resistant strains of staphylococci by polymerase chain reaction. J. Clin. Microbiol. 1991, 29, 2240-2244. https://doi.org/10.1128/JCM.29.10.2240-2244.1991

[11] Stuhlmeier, R.; Stuhlmeier, K.M. Fast, simultaneous, and sensitive detection of Staphylococci. J Clin Pathol 2003, 56: 782-785. https://doi.org/10.1136/jcp.56.10.782

[12] Asghar AH. Molecular characterization of methicillin-resistant Staphylococcus aureus isolated from tertiary care hospitals. Pak J Med Sci 2014;30:698-702. https://doi.org/10.12669/pjms.304.4946

[13] [Ng, L.K.; Martin, I.; Alfa, M.; Mulvey, M. Multiplex PCR for the detection of tetracycline resistant genes. Mol. Cell. Probes 2001, 15, 209-215. https://doi.org/10.1006/mcpr.2001.0363

[14] Gomes, R.M.; Bomfim, M.R.Q. Potential Spread of Methicillin-Resistant Staphylococcus aureus Recovered from Patients with Bloodstream Infection. Chemother. Open Access 2015, 4. https://doi.org/10.4172/2167-7700.1000149

[15] Omoe, K.; Hu, D.L.; Takahashi-Omoe, H.; Nakane, A.; Shinagawa, K. Comprehensive analysis of classical and newly described staphylococcal superantigenic toxin genes in Staphylococcus aureus isolates. FEMS Microbiol. Lett. 2005, 246, 191-198. https://doi.org/10.1016/j.femsle.2005.04.007

[16] Pinto, B.; Chenoll, E.; Aznar, R. Identification and typing of food-borne Staphylococcus aureus by PCR-based techniques. Syst. Appl. 
Microbiol. 2005, 28, 340-352. https://doi.org/10.1016/j.syapm.2005.01.002

[17] Clinical and Laboratory Standards Institute. Supplement M100. In Performance Standards for Antimicrobial Susceptibility Testing, 27th ed.; Clinical and Laboratory Standards Institute: Wayne, PA, USA 2017.

[18] Schmidt, T., Kock, M.M. and Ehlers, M.M. Diversity and antimicrobial susceptibility profiling of staphylococci isolated from bovine mastitis cases and close human contacts. J. Dairy Sci. 2015,98, 6256- 6269. https://doi.org/10.3168/jds.2015-9715

[19] Wang, D., Zhang, L., Zhou, X., He, Y., Yong, C., Shen, M., et al. (2016). Antimicrobial susceptibility, virulence genes, and randomly amplified polymorphic DNA analysis of Staphylococcus aureus recovered from bovine mastitis in Ningxia, China. J Dairy Sci 99: 9560-9569. https://doi.org/10.3168/jds.2016-11625

[20] Hennekinne, J. A., De Buyser,M. L., and Dragacci, S. Staphylococcus aureus and its food poisoning toxins: characterization and outbreak investigation. FEMS Microbiol. Rev. 2012,36, 815-836. https://doi.org/10.1111/j.1574-6976.2011.00311.x

[21] Rong, D., Wu, Q., Xu, M., Zhang, J. and Yu, S. Prevalence, virulence genes, antimicrobial susceptibility, and genetic diversity of Staphylococcus aureus from retail aquatic products in China. Front. Microbiol. 2017, 8:714. https://doi.org/10.3389/fmicb.2017.00714

[22] World Health Organization Antibiotic Resistance. Geneava, Switzerland Available online: https://www.who.int/news-room/factsheets/detail/antibiotic-resistance

[23] Klein, E. Global increase and geographic convergence in antibiotic consumption between 2000 and 2015.Proc. Natl. Acad. Sci. USA. 2018, 115, E3463. https://doi.org/10.1073/pnas.1717295115

[24] Zehra, A.; Singh, R.; Kaur, S.; Gill, J.P.S. Molecular characterization of antibiotic-resistant Staphylococcus aureus from livestock (bovine and swine). Vet. World 2017, 10, 598-604. https://doi.org/10.14202/vetworld.2017.598-604

[25] Van Boeckel, T.P.; Gandra, S.; Ashok, A.; Caudron, Q.; Grenfell, B.T.; Levin, S.A.; Laxminarayan, R. Global antibiotic consumption 2000 to 2010: An analysis of national pharmaceutical sales data. Lancet Infect. Dis.2014, 14, 742-750. https://doi.org/10.1016/S14733099(14)70780-7

[26] Chu, C.; Yu, C.; Lee, Y.; Su, Y. Genetically divergent methicillin-resistant Staphylococcus aureus and sec-dependent mastitis of dairy goats in Taiwan. BMC Vet. Res. 2012, 8, 39. https://doi.org/10.1186/17466148-8-39

[27] Cortimiglia, C.; Bianchini, V.; Franco, A.; Caprioli, A.; Battisti, A.; Colombo, L.; Stradiotto, K.; Vezzoli, F.; Luini, M. Short communication: Prevalence of Staphylococcus aureus and methicillin-resistant S. aureus in bulk tank milk from dairy goat farms in Northern Italy. J Dairy Sci 2015, 98, 2307-2311. https://doi.org/10.3168/jds.2014-8923

[28] Alzohairy, M.A. Colonization and antibiotic susceptibility pattern of methicillin resistance Staphylococcus aureus (MRSA) among farm animals in Saudi Arabia. J. Bacteriol. Res. 2011, 3, 63-68.

[29] Rong, D.; Wu, Q.; Xu, M.; Zhang, J.; Yu, S. Prevalence, virulence genes, antimicrobial susceptibility, and genetic diversity of Staphylococcus aureus from retail aquatic products in China. Front. Microbiol. 2017, 8, 1-10. https://doi.org/10.3389/fmicb.2017.00714

[30] Elhassan, M.M.; Ozbak, H.A.; Hemeg, H.A.; Elmekki, M.A.; Ahmed, L.M Absence of the mecA gene in methicillin resistant Staphylococcus aureus isolated from different clinical specimens in Shendi City, Sudan. Biomed Res. Int. 2015, 2015 https://doi.org/10.1155/2015/895860

[31] Garcia-Alvarez, L.; Holden, M.; Lindsay, H.; Webb, C.; Brown, D.; Curran, M. Methicillin-resistant Staphylococcus aureus with a novel mecA homologue in human and bovine populations in the UK and Denmark: a descriptive study. Lancet 2011, 11, 595-603. https://doi.org/10.1016/S1473-3099(11)70126-8

[32] Walther B,Wieler LH, Vincze S et al. MRSAvariant in companion animals. Emerg Infect Dis 2012; 18: $2017 \quad-20$ https://doi.org/10.3201/eid1812.120238
[33] AA, Nsreen MK, Rasha HEI, Mona MA. Evaluation for the Novel mecC Methicillin Resistance among Methicillin Resistant Staphylococcal Isolates in two Egyptian University Hospitals. Arch Clin Microbiol 2017, 9.1:71. https://doi.org/10.4172/1989-8436.100071

[34] Hao, H.; Dai, M.; Wang, Y.; Huang, L.; Yuan, Z. Key genetic elements and regulation systems in methicillin-resistant Staphylococcus aureus. Future Microbiol. 2012, 7, 1315-1329. https://doi.org/10.2217/fmb.12.107

[35] Li, X.; Fan, X.; Xiong, Y.; Zhong, Z.; Tang, H.; Feng, P.; Zhou, T. A Study of the Regulating Gene of femA from Methicillin-resistant Staphylococcus aureus Clinical Isolates. J. Int. Med. Res. 2013, 36, 420-433. https://doi.org/10.1177/147323000803600306

[36] Roberts, M.C. (1996) Tetracycline resistance determinants: Mechanisms of action, regulation of expression, genetic mobility, and distribution. FEMS Microbiol. Rev., 19: 1-24. https://doi.org/10.1111/j.15746976.1996.tb00251.x

[37] Thorberg, B.M., Danielsson-Tham, M.L., Emanuelson, U. and PerssonWaller, K. (2009) Bovine subclinical mastitis caused by different types of coagulase-negative Staphylococci. J. Dairy Sci., 92 4962-4970. https://doi.org/10.3168/jds.2009-2184

[38] Booth, N. and Mcdonald, L.E. Farmacologiae Terapêuticaem Veterinária. 6th ed. Guanabara Koogan, Rio de Janeiro.1992, 997.

[39] Abd El-Razik KA, ArafaAA, Hedia RH and IbrahimES. Tetracycline resistance phenotypes and genotypes of coagulase-negative staphylococcal isolates from bubaline mastitis in Egypt. Vet World 2017, 10: 702-710. https://doi.org/10.14202/vetworld.2017.702-710

[40] Osman, K.M., Abd El-Razik, K.A., Marie, H.S.H. and Arafa, A. Coagulasenegative Staphylococci collected from bovine milk: Species and antimicrobial gene diversity. J. Food Saf. 2016, 36: 89-99. https://doi.org/10.1111/jfs.12216

[41] Grossman TH. Tetracycline antibiotics and resistance. Cold Spring Harb Perspect Med. 2016 https://doi.org/10.1101/cshperspect.a025387

[42] Köck, R.; Harlizius, J.; Bressan, N.; Laerberg, R.;Wieler, L.H.;Witte,W.; Deurenberg, R.H.; Voss, A.; Becker, K.; Friedrich, A.W. Prevalence and molecular characteristics of methicillin-resistant Staphylococcus aureus (MRSA) among pigs on German farms and import of livestockrelated MRSA into hospitals. Eur. J. Clin. Microbiol Infect Dis 2009; 28 1375-1382. https://doi.org/10.1007/s10096-009-0795-4

[43] Mkize, N.; Zishiri, O.T.; Mukaratirwa, S. Genetic characterization of antimicrobial resistance and virulence genes in Staphylococcus aureus isolated from commercial broiler chickens in the Durban metropolitan area,South Africa. J S Afr Vet Assoc 2017; 88: 1-7. https://doi.org/10.4102/jsava.v88i0.1416

[44] Dweba, C. C.; Zishiri, O. T.; EL Zowalaty, E. M. E. Isolation and Molecular Identification of Virulence, Antimicrobial and Heavy Metal Resistance Genes in Livestock - Associated Methicillin Resistant Staphylococcus aureus. Pathogens 2019, 79, 8, 1-21. https://doi.org/10.3390/pathogens8020079

[45] Soares, L.C., Pereira, I.A., Pribul, B.R., Oliva, M.S., Coelho, S.M.O. and Souza, M.M.S. Antimicrobial resistance and detection of mecA and blaZ genes in coagulase-negative Staphylococcus isolated from bovine mastitis. Pesqui. Vet Bras 2012, 32: 692-696. https://doi.org/10.1590/S0100-736X2012000800002 